Circuits and Systems: An International Journal (CSIJ), Vol.5, No.1/2/3, July 2018

\title{
Criticisms Of The Future AVAilability IN SUSTAINABLE GENDER GOAL, ACCESS TO LAND AND NON-LAND UNDER The POPUlations AND Climate Change
}

\author{
Kasun D Ramanayake R.A \\ Department of Economics, University of Florence, Italy
}

\begin{abstract}
This paper begins with the understanding that criticizes in one of the Sustainable development gender goal, "Undertake reforms to give women equal rights to economic resources, as well as access to ownership and control over land and other forms of property " under the Populations growth and Climate Change. Because an increasing population generates a number of challenges for today and also in the future world. According to the results of World Population Prospect 2015, world population reached 7.3 billion as of mid-2015 and continually increasing to 11.2 billion in 2100, In the meanwhile world tempter anticipated to increase between $2.6 \mathrm{RCP}$ and 8.6 RCP, therefore, world average sea level increase in between from $0.4 \mathrm{~m}$ and $0.9 \mathrm{~m}$ in 2010 (IPCC,2014). as a reason world need to face negative demographical change send of this century. According to gender goals, UN wants to increase the women's new land access. but it generates the number of unsustainable results in future, because climate change and population growth affected to huge density and land ownership problems. Therefore in this paper criticized this Sustainable Development Goal and gender indicators, as same as discussed technological and sustainable suggestions under the Populations growth and Climate Change.
\end{abstract}

\section{KEYWORDS}

Climate Change, Populations, Indicator, Availability of Land

\section{INTRODUCTIONS}

Research from a range of source including the World Bank, the United Nations Food and Agriculture Organization, the OECD Development Centre, civil society organizations, and academic institutions also point to another key finding illustrates ,women land ownership effects gender inequality and sustainable developments problem in future world . "The world women property ownership was represented less than 2 percentage of the total property ownership in world"1.comparison to the men, especially in developing world, woman are 5 times less likely than men to own land, and their farms are usually smaller and less spaces 2".but world need to understand "Discrimination against women and girls impairs progress in all other areas of development," 3 because there is an evident correlation between gender inequality, societal poverty, eradicate extreme poverty and hunger and the failure to respect, protect and fulfill these rights for women. the rights of the land ownerships for women as a basic element of the sustainable development Rights to land and property include the right to own, use, access, control, transfer, exclude, inherit and otherwise make decisions about land and related resources. 
Circuits and Systems: An International Journal (CSIJ), Vol.5, No.1/2/3, July 2018

Secure rights to land are rights that are clearly defined, long-term, enforceable, appropriately transferable, and legally and socially legitimate whole including to this concept (Gómezes and Tran,2012) as well as the world bank reports illustrates "only independent or joint ownership can ensure that women have access to and control over land based earnings.4" Additionally, as the World Bank recognizes, "lights to land and natural resources increase a woman's bargaining power within the household, which results in increased allocation of household resources to children and women as well as increased household welfare5."

According to the Millennium Development Goals (MDG), Fisheries and Forests in the whole of National Food Security is main part of the gender equality "The Guidelines recognize the importance of gender equality in land tenure as critical to the strategies to reduce hunger and poverty, support sustainable development, and enhance the environment" ${ }^{6}$ According to a World Bank report, "only independent or joint ownership can ensure that women have access to and control over land based earnings." "but the transaction to the MDG to SDG (Sustainable development goals) this concept were changed in the limited conditions but overall targets of the those two policies shows similarity conditions in gender equality. According to the introductions summary, all past study reviews strongly construct, there was a steady relationship between women property ownership and the all economics component in the world specially, hunger and poverty, women empower and gender equality. As a reason Sustainable development Goals (SDG) adding the one of main targets increasing women land ownership, Generally, it's really the effective movement for the gender inequality in future but in this paper mainly discuss the matter of this SDG of "Achieve gender equality and empower all women and girls" under this goal UN introduces 17 targets, those 17 targets are categorized into 5 groups 1. Agricultural work and food security 2 Access to land and non-land assets 3 Water and sanitation 4 Health impacts of indoor and outdoor air pollution 5 Female participation in environmental institutions and education(GEEU,2016 ) $)^{8}$, but problem is really correlated in target 2 "Access to land and non- land assets" because can world increasing the land and nonland assets in future?, specially under effects of the climate change and population. as a reason, this paper mainly highlights the problems of this target and how to effected to this for unsustainability, but impotent argumentation was world cannot stop the gender equality target, but in same time world need to balance land access according to the sustainability conditions, this paper also discuss the those conditions in deferent views .

\section{Methodology}

Paper approach mainly based on case-study method while secondary data is also taken for the analysis. This means qualitative methods are meaningfully integrated. Selection of the areas on takes general discussion of the world (used completely secondary data analyzes). Data need and data source should include both primary as well as secondary research and also social and economic research variables use to qualitative analyzes those are, especially in the world organizations reporters were highly valuated the base contents (ex: ipcc reports, world populations reports, un repots ... etc. ) secondary data used on the analytical qualitative methods to be used for achieving the objectives of the paper. The analytical methods to be used for achieving the objectives 1) to understand the factors that causes: qualitative annualize use to case study and key- information 2) to understand environment problems, density problems, social problems: with published and unpublished reason from access to land and non-land assets category how to effect the world using case-study method also impact of goal analysis qualitative analysis ,effectiveness of existing policies: to be change the policy, identification of 
Circuits and Systems: An International Journal (CSIJ), Vol.5, No.1/2/3, July 2018

social and environment effects and analytical tools : case-study method .finally expected outcomes of the study and descriptive significance 1. Disclose the magnitude of future problem for the world 2. Suggest measures for strengthening existing policies and programs 3. Make appropriate recommendations for formulating new policies and programs 4. Disseminate findings to policy makers, academics, other responsible bodies and the general public PROBLEMS STATEMENT"SDGs are likely to fail unless far more attention is given to addressing governance challenges crucial to their implementation"'. Actually those are not really focused on the whole economics forecast in future, specially population and climate changes. "goal 13 is a classic example. Those affected in the short term, such as fossil fuel companies and their workers, will perceive themselves as "losers" if they are forced to change, even though society as a whole will be a "winner" in the long-term by avoiding the tremendous risks and impacts of runaway climate change" $"$. According to the gender SDG, mainly indicators used for the meshed the availability of data of women and men on the environment and sustainable development issues and gender inequality. Those main 17 indicators are categorized into 5 groups 1 . Agricultural work and food security 2.Access to land and non-land assets 3.water and sanitation, 4.health impacts of indoor and outdoor air pollution 5.female participation in environmental institutions and education. According to that in sustainable goals are not dependent only on education such as done in minimums goals therefore this was a significant movement for the society .but in problems is being in access to land and non-land assets category, because all concepts of the SDG gender targets forecast on the improving land access of the women (in quantitative improvement of the yield), according to the future effect of the population and climate change will decrease to world land space and residential space as a reason, is this goal really suitable to the future therefore, this paper mainly discuss, how to effect this goal for the un-sustainability? (limitations of Land Access indicators)

\section{INDICATORS (GENDER AGRICULTURE LAND ACCESS)}

"A series of long-term trends, from climate change to demographics, is already reshaping the global landscape for policymakers and practitioners, just as they set their sights on implementing the Sustainable Development Goals by $2030^{11}$ " (Mario Pezzini, 2016). According to that increasing land access is suitable for the sustainability in future world. This that main point which world need contraception in whole time, Specially in agriculture Land access in worldwide because ,"The international development community has recognized that agriculture is an engine of growth and poverty reduction in countries where it is the main occupation of the poor ${ }^{12}$ " (World Bank, 2007)Although there are the global situations that women's land rights are the necessary condition for the establishing of food security and rural development, according to the reasons statistics highlighted of these rights are still lacking. Indeed, the lack of clear and combine statistics on land ownership and land management- that are correlated with sex .it is fundamental principle for developing policy responses and monitoring of, inequalities faced by women and men in rural areas (Doss et al., 2015)therefore the world needs to measure the sex (gender) aggregate statically and theoretical movement according to the changing time in rural areas, because the "FAO Statistics Division began encouraging countries undertaking an agricultural census to compile and report key sex-disaggregated structural indicators, including the share of agricultural holders by sex:" "This is a measure of management giving by the indicators, not only landownership, also take considerations women's responsibilities and management in agriculture and identified actual value of the land ownership and management at the plot levels (WCA 2010) 


\subsection{INDICATOR 1}

Agricultural holders by sex or gender, measures the percentage of female and male agricultural holders out of total agricultural holders. The indicator is created as follows

$$
\left(\frac{\text { Female agriculture holder }}{\text { Total agriculture holder }}\right) \cdot 100:\left(\frac{\text { Male agriculture holder }}{\text { Total agriculture holder }}\right) \cdot 100
$$

The agricultural holder is illustrated in agricultural concept as: "The civil or juridical person who makes the major decisions regarding resource use and exercises management control over the agricultural holding operation. The agricultural holder has technical and economic responsibility for the holding and may undertake all responsibilities directly, or delegate responsibilities related to day to day work management to a hired manager ${ }^{14 \%}$ (FAO, 2005).

An agricultural holding is defined as: "An economic unit of agricultural production under single management comprising all livestock kept and all land used wholly or partly for agricultural production purposes, without regard to title, legal form, or size. Single management may be exercised by an individual or household, jointly by two or more individuals or households, by a clan or tribe, or by a juridical person such as a corporation, cooperative or government agency. The holding's land may consist of one or more parcels, located in one or more separate areas or in one or more territorial or administrative divisions, providing the parcels share the same production means, such as labor, farm buildings, machinery or draught animals ${ }^{15 "}$ (FAO 2005) This indicator represents the management of agricultural holdings by gender, classification of the extent how to women and men have the management responsibility of agricultural process of production. Sometime holder is the owner and sometime not but. "While agricultural holdings typically are land holdings, they may also comprise other agricultural production resources, and in some cases only non-land resources ${ }^{16 " n o r m a l l y, ~ t h e ~ w o r l d ~ r e p r e s e n t ~ m u c h ~}$ more single agricultural holding as a reason the join management was lower than signal agriculture holding therefore "the total number of holders would therefore be larger than the total number of holdings. ${ }^{17 "}$ this indicator data sources are mainly coming for the Agricultural National and Holders censuses

\subsection{INDICATOR 2}

Measures the share of female and male agricultural landowners in the total population of landowners

$$
\left(\frac{\text { Female agriculture landowner }}{\text { Total agriculture landowner }}\right) \cdot 100:\left(\frac{\text { Male agriculture landowner }}{\text { Total agriculture landowner }}\right) \cdot 100
$$

this flowing indicator mainly illustrates the landownership in gender vices .specially this indicator combining with the property law because land property ownership have to be legalized under the 
law and it needs to be an access for owner his property anytime and anywhere. Therefore this indicator indirectly combines with the legal conditions therefore "ownership, it may also include proxies, such as the right to use, sell or bequeath the land, or the right to use it as legal collateral $^{18 "}$.in this indicator also represent similarity condition which was sawed in 1 indicator as same, because land ownership can see in different peptones which are single ownership and someone's multi ownerships and some land had multi borders which owned by the same family. Data sources. The data used to construct Indicator 2 typically stems from large-scale household surveys in which questions on landownership for individual household members are included in an agricultural module (LSMS approach)

\subsection{INDICATOR 3}

Measures the single male and female land ownership under the total male and female total populations, and also this indicator realizing the sole and joint ownership under the women and by men and for any ownership

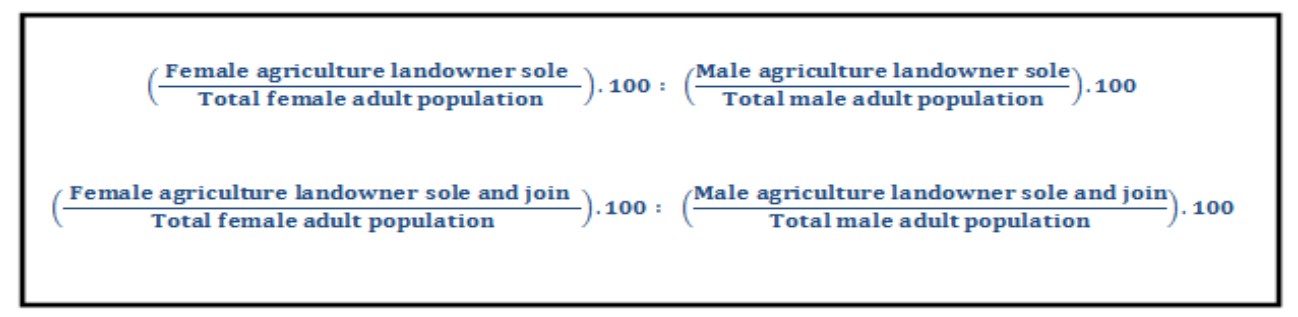

Specially this indicator represents the property rights of the man and women. if they are like to sole or joint their own property, this indicator measures this right under the man and women total population the main sources of data to construct this indicator are large-scale household surveys that include questions on individual land ownership. There are currently two potential sources of nationally representative data for constructing Indicator 2.

\subsection{INDICATOR 4}

Measures the share of the agricultural land area that is owned by women, men, and jointly by men and women, using the total land area owned by households measures the share of the agricultural land area that is owned by women, men, and jointly by men and women, using the total land area owned by households

$$
\begin{gathered}
\left(\frac{\text { Agriculutre land area owned by the women }}{\text { Total Agriculutre land area owned by the } \mathrm{HH}}\right) \cdot 100:\left(\frac{\text { griculutre land area owned by the men }}{\text { Total mgriculutre land area owned by } \mathrm{HH}}\right) \cdot 100 \\
\left(\frac{\text { Agriculutre land area owned by the womenand men }}{\text { Total Agriculutre land area owned by the } \mathrm{HH}}\right) \cdot 100
\end{gathered}
$$

\subsection{INDICATOR 5}

Measures the share of the agricultural land value that is owned by women, men and jointly, using the total value of land owned by households. 
$\left(\frac{\text { Agriculutre land value owned by the women }}{\text { Total Agriculutre land value owned by the } \mathrm{HH}}\right) \cdot 100:\left(\frac{\text { griculutre land value owned by the men }}{\text { Total mgriculutre land value owned by } \mathrm{HH}}\right) \cdot 100$

$\left(\frac{\text { Agriculutre land area owned by the womenand men }}{\text { Total Agriculutre land value owned by the HH }}\right) \cdot 100$

Indicator 3,4,5 data collect was represented similar pattern large-scale household surveys that include questions on individual landownership. Similarly to Indicator 4, this indicator requires plot level data on value and ownership which is typically only available in specialized agricultural surveys

Overall this chapter illustrates the land and non-land access data measures in world but the all five indicators mainly forecasted on the quantitative analysis or analyzing the land and land value data only. It was the special think which is representing this indictors.

\section{Limitations AND AvaILABILITy OF INDICATORS}

According this chapter mainly discuss about limitations this indicators in two different ways on one hand illustrates limitations each by each in indicator on the other hand (second part) try to demonstrates the common limitations of the indicators combine with the SDG gender target (Increasing the women land and non-land Access) under the population and climate change effect he various analyses presented in this paper provide new insights into the gendered patterns of land ownership. Our best estimates from a review of 17 large scale micro-studies indicate that women are disadvantaged relative to men in nearly all measures of land ownership and bundles of rights; however, the gender gap varies widely. These statistics are typically more equitable for management indicators, or for land with use or access rights only, while they are less equitable for indicators based on reported or documented ownership

\begin{tabular}{|c|c|c|}
\hline Indicator & Limitations & Availability \\
\hline 01 & $\begin{array}{l}\text { 1) Measured only at the holding level and } \\
\text { while does not capture management } \\
\text { within the holding } \text { 1 }^{*} \\
\text { 2) this concept is mainly basted on the } \\
\text { managerial decisions and landownership } \\
\text { within the holding in addition to the sex of } \\
\text { the holder and it illustrates the availability } \\
\text { of the intra-holding data in the future } \\
\text { 3) some countries should adopt for the } \\
\text { minimum size of the holdings included in } \\
\text { the census (often due to implementation } \\
\text { constraints), leaving out holdings that fall } \\
\text { below a certain value } \text { 2.* }^{*} \\
\text { 4) yearly collection of this indicator is likely } \\
\text { to be redundant }\end{array}$ & $\begin{array}{l}\text { The FAO and GLRD World } \\
\text { Programmed of Agricultural } \\
\text { Censuses follow a 10-year cycle. } \\
\text { Every } 10 \text { years new guidelines and } \\
\text { recommendations are provided to } \\
\text { countries to help them generate } \\
\text { internationally comparable figures } \\
\text { on the structure of agriculture }\end{array}$ \\
\hline
\end{tabular}


Circuits and Systems: An International Journal (CSIJ), Vol.5, No.1/2/3, July 2018

\begin{tabular}{|c|c|c|c|}
\hline 02 & & $\begin{array}{l}\text { Land ownership that affects this and the } \\
\text { following indicators. The indicator is } \\
\text { collected in different years, depending on } \\
\text { when surveys are conducted in individual } \\
\text { countries. This may negatively affect }\end{array}$ & $\begin{array}{l}\text { shows the available data for this } \\
\text { indicator in the GLRD\# based on } \\
\text { data analysis by Deere et al. ( } 2012) \text {, } \\
\text { Deere \& Leon (2013), Doss et al. } \\
\text { (2011) and Kieran et al. (2015) }\end{array}$ \\
\hline
\end{tabular}

Table 1. Limitations and availability of Indicators

$1^{*}$ some of the countries in world use combining the agriculture household and agricultural holding under their land ownership and landless situations .but it was not common in every time, it depends on the agriculture management under the technical and economic responsibility

$2 *$ for the example, some countries should adopt for the minimum size of the holdings included in the census.

\# GLRD = The Gender and Land Rights Database

\begin{tabular}{|c|c|c|}
\hline Indicator & Limitations & Availability \\
\hline $\mathbf{0 3}$ & $\begin{array}{l}\text { Collecting data on land ownership in terms of } \\
\text { reliability of people's response about } \\
\text { whether they are owners as and lack of } \\
\text { documentation }\end{array}$ & $\begin{array}{l}\text { The indicator is available in the } \\
\text { GLRD as of May } 2015 \text { for } 16 \\
\text { countries, based on the analysis by } \\
\text { Doss et al. (2015) and Kieran et al. } \\
\text { (2015); }\end{array}$ \\
\hline 04 & $\begin{array}{l}\text { This does not tell us how many men and how } \\
\text { many women own land }{ }^{3 *}\end{array}$ & $\begin{array}{l}\text { As of May } 2015 \text {, the GLRD has this } \\
\text { indicator available for six countries in } \\
\text { Sub-Saharan Africa and for three } \\
\text { countries in Asia22, based on the } \\
\text { analysis by Doss et al. (2015) and } \\
\text { Kieran et al. (2015) }\end{array}$ \\
\hline 05 & $\begin{array}{l}\text { Challenges with collecting data on land } \\
\text { values. }\end{array}$ & $\begin{array}{l}\text { Data are currently only available for } \\
\text { five countries for this indicator in the } \\
\text { GLRD, based on the analysis by Doss } \\
\text { et al. (2015). } 23 \text { The results are shown } \\
\text { More surveys are available for } \\
\text { processing to add to the data } \\
\text { availability }\end{array}$ \\
\hline
\end{tabular}

Table 2. Limitations and availability of Indicators

Those 5 indicates were illustrated one common view, it was quantitative change in the property of land and Non-land access in gender vices, simply change the land access of the world and also those 5 indicators were represented and joined very time of the analyzing the GLRD data (The Gender and Land Rights Database) therefore the every time the SDG are representing this concept under the gender equality targets but there was a common challenge for the future, the second part of this chapter illustrate this matter,"can world increasing land access under the climate change and population effects?"

$3^{*}$ While it would not add to the picture in terms of gender inequalities it would show, degree productive land is controlled by non-households and provide a sense of the importance of those other players in agriculture 


\section{Population Effect To The Land Access}

The world population reached 7.3 billion as of mid-2015, implying that the world has added approximately one billion people in the span of the last twelve years. Sixty per cent of the global population lives in Asia (4.4 billion), 16 per cent in Africa (1.2 billion), 10 per cent in Europe (738 million), 9 per cent in Latin America and the Caribbean (634 million), and the remaining 5 per cent in Northern America (358 million) and Oceania (39 million). China (1.4 billion) and India (1.3 billion) remain the two largest countries of the world, both with more than 1 billion people, representing 19 and 18 per cent of the world's population, respectively

\begin{tabular}{|c|c|c|c|c|c|}
\hline \multirow{2}{*}{\multicolumn{2}{|c|}{ Major are }} & \multicolumn{4}{|c|}{ Population (millions) } \\
\hline & & 2015 & 2030 & 2050 & 2100 \\
\hline 1) & World & 7349 & 8501 & 9725 & 11213 \\
\hline 2) & Africa.............. & 1186 & 1679 & 2478 & 4387 \\
\hline 3) & Asia & 4393 & 4923 & 5267 & 4889 \\
\hline 4) & Europe & 738 & 734 & 707 & 646 \\
\hline & Latin America and the & & & & \\
\hline & Caribbean ....................... & 634 & 721 & 784 & 721 \\
\hline 6) & Northem America............ & 358 & 396 & 433 & 500 \\
\hline & Oceania & 39 & 47 & 57 & 71. \\
\hline
\end{tabular}

Table 3. Population Of The World And Major Areas, 2015, 2030, 2050 And 2100, According To The Medium- Variant Projection

Source: United Nations, Department of Economic and Social Affairs, Population Division (2015).World Population Prospects: The 2015 Revision. New York: United Nations

"Population growth represents 1.18 percent per year last two years but ten years ago the world population was growing by 1.24 per cent per year or approximately ${ }^{19 "}$ an additional 83 million people for total population to annually. The world population is projected to increase by more than one billion people within the next 15 years, reaching 8.5 billion in 2030 , and to increase further to 9.7 billion in 2050 and 11.2 billion by 2100 (UNPR 2015)

It took hundreds of thousands of years for the world population to grow to 1 billion - then in just another 200 years or so, it grew sevenfold. In 2011, the global population reached the 7 billion mark, and today, it stands at about 7.5 billion. This dramatic growth has been driven largely by increasing numbers of people surviving to reproductive age, and has been accompanied by major changes in fertility rates, increasing urbanization and accelerating migration. These trends will have far-reaching implications for generations to come. The recent past represented enormous changes in fertility (birth) rates and life expectancy. In the early 70, women had on average 4.5 children, total fertility for the world had fallen to around 2.3 children per woman in today. Meanwhile, average Global life spans have risen, from 64.8 years in the early 1990 s to 70.0 in 2017 . In the meantime, the world is showing high levels of 
Circuits and Systems: An International Journal (CSIJ), Vol.5, No.1/2/3, July 2018

urbanization and accelerating migration. in 2050 about 66 per cent of the world population will be living in cities.(UNDP 2014)The higher growth in the world population after the sound world war is positively the result of advance in modern medicines and improvements in living and life standards. as a reason reduced infant, child, and maternal death rate, contributing to an increase in life expectancy. Also, child birth rate levels have declined, The world population will continue to grow up for until the end of this century. This is the result of population trends Because of improved survival rates and past high childbirth levels, This will be affected by an increasingly large number of births, after 2060 it will almost exclusively be driven by fertility levels in the world's least developed countries. Reaching population nearly 8 billons today, it is generated many problems in recently and population continently increasing nearly 11.2 billon in between today and 2100 (UNPR 2015) in this effect makes a number of problems in the future world which is really serious problems. and UNPR report mentioned adding the new 4 billons total population end of this century 3 billon is generated by African region, it means African population is most highlighting factor of the future world population. The problem is begging around world resources, are there all land space and natural resources enough for the total population in 2100 ? The simple answer is defiantly in not enough for saving the human in this planet theirs effects are generated so many interrelated challenges for the world RESIDENCE in future, such as health problems, food, and SPACE PROBLEMS, human right, energy, challenges law and institutional and etc. Unprecedentedly, today, the world population is encountering unfamiliar human-induced changes in the lower and middle atmospheres and world-wide depletion of various other natural systems (e.g. soil fertility, aquifers, ocean fisheries, and biodiversity in general). "Beyond the early recognition that such changes would affect economic activities, infrastructure and managed ecosystems, there is now recognition that global climate change poses risks to Human Population ${ }^{20 "}$ (WHO). On other hand Agriculture land in the 21st century faces multiple challenges: it has to produce more food and fiber to feed a growing population with a smaller rural labor force, more feedstock's for a potentially huge bio energy market, contribute to overall development in the many agriculture-dependent developing countries, adopt more efficient and sustainable production methods and adapt to climate change.(HOW;2009) therefore, according to the SDG gender targets "can world increasing land access under the climate change and population effects ?" because according to the populations growth agricultural land use is steeper than the slope of the location rent function for forestry land use. Therefore, rural lands with relatively greater accessibility to markets and the population are more likely to be converted to or retained in agricultural land use, and rural lands in remote locations are more likely to be converted to or retained in forestry use. A number of empirical studies of tropical deforestation model the effect of accessibility to markets on conversion of undisturbed forests to agriculture (Chomitz and Gray; Parks, Barbier, and Burgess).it clearly represents if the world needs to the incoming land access (whatever access of men or women ) the only option is using the rural forest lands, again this paper argue thus is the sustainability which world hope to make while protect the gender equality because density problems is really effected to the future world Another obvious population pattern is the big difference in population between Earth's most populated countries China and India and other countries. (NASA 2016) in 2100 estimations, Asia and North and South American regions are most density areas, in mean time whole over the world completely filling the peoples because this data represented only in 9.5 billons only, but real effect is nearly 11.2 billion,

\section{Climate Effect To The Land ACCess}

"This environment change directly affected by the negative change of the air and water 
Circuits and Systems: An International Journal (CSIJ), Vol.5, No.1/2/3, July 2018

pollution, loss of biodiversity, wildlife habitat fragmentation, and increased flooding. And also it makes combining effects of climate change, therefore these effects are changing land base is privately owned therefore it is important to understand how socioeconomic and environmental factors affect private landowners' decisions concerning land use. ${ }^{21}$ "Availability of the land use depend on modeled at the individual or aggregate level, especially describe areas or proportions and certain land use categories within a well-defined geographic area, this geographical exceptions dependent on the social economics and environment situations in world(Alig and Healy; Parks and Murray; Stavins and Jaffe; Zhang and Nagubadi). Final expiations of the models of land use allocation that not only utilize aggregate but also environment estimate proportions of land shares more valuable for the land allocation in today (Miller and Plantinga), According to the SDG in gender targets really illustrated only utilizations in women's propositions of the land share,therefore the problem is this target. really unmatched for the sustainability correct conditions of the the future land access dependent on the large scale models, spatial variability of prices, economic and climatic conditions and also in addition to site characteristics and location, also to include variables such as observable returns to agriculture, forestry, and residential uses (Lubowski, Plantinga, and Stavins; Miller and Plantinga) or property taxes (Polyakov and Zhang).therefore the climate and environment effects are strong conditions for the future land access. And also "increasingly important as conditions change and the likelihood of major ecological shifts increases. These changes will decrease the relevance of current models and practices for managing ecological resources and fisheries stocks, LAND, leading the management of many marine resources into uncharted waters. Nonetheless, no regret management strategies that reduce the impact of local stresses while maintaining ecological resilience will play an increasingly important role as the climate changes ${ }^{22}$ ".

"Actions that reduce the flow of nutrients and sediments from coastal catch- means, for example, as well as those that reduce activities such as the deforestation of mangroves and the overfishing of key ecological species (e.g., herbivores) ${ }^{23}$ ", "will become increasingly important as the impacts of climate change mount. NATURAL RESOURCE MANAGEMENT must also remain flexible in order to absorb the sudden and nonlinear changes that are likely to characterize the behavior of most ecosystems into the future. ${ }^{24 \text { ' }}$ Land is the Natural recourse, According to the all of the lecturer represented the world cannot use much more natural lands under this population and climate change conditions but SDG gender targets faces on the increasing land access ,therefore world need ask is this correct movement for the future

As same as the world density problem highly effect to the world law and pieces in end of the this century In mean time increasing average world tempter in between 2.6 RCP to 8.6 RCP therefore this effect rising the average sea level from $0.4 \mathrm{~m}$ to $0.9 \mathrm{~m}$ between 2010 and. as a reason world need anticipate really negative demographical change end of this century because world land spaces to melt to the sea in this effect according to the scientifically annualize represented London, Paris, Mississippi Miami and mush more economic and demographical valuable places despaired in this plant (IPCC 2014) ${ }^{25}$ ".the overall idea of upper chapter mainly highlighted world population is increasing and makes huge density problem and also climate change both affected to the makes real property problem in the future world, therefore, land or property is the much valuable component in future society. but according to the 17 indicators second category (Access To Land and Non-Land Assets) is actually suitable for the society and sustainability because according to the this accept UN will face to future this targets to take success 
Circuits and Systems: An International Journal (CSIJ), Vol.5, No.1/2/3, July 2018

According to overall idea of this targets illustrates, if UN wants to reach this target need to be an increase the land use in future but the matter is, Can World increase the land access in future ?, because world density is much higher in future world and mean time climate change affected to decreasing the land if the world need to increase the land access the only option is deforestation then the next chapter illustrate population, climate change and deforestation (Green Effects ) how to effects to the future sustainability.

\section{RECOMMENDATIONS}

"Important factors affecting the allocation of land between rural and developed uses, between agricultural and forestry uses ${ }^{26}$, First, "we implement a spatially explicit econometric model of land use land cover change that models changes between rural and urban uses, between agricultural and forestry uses, and between forest cover types. This model can be used to forecast land use change at a small (sub watershed and watershed) scale and serve as a useful tool for ecologists, hydrologists ${ }^{27}$ ", and city and county planners. Second, our model simultaneously describes land use changes occurring among several different land use classes as opposed to modeling changes for each initial land use separately. "This allows better utilization of land use change data where probabilities of changes are relatively low and probabilities of retention are relatively high. Third, we find that accessibility to population drives not only the transition of rural land uses to developed land and allocation between forestry and agricultural uses, but also transition between forest cover types (forest management types) ${ }^{28 "}$.therefore land access is directly effected to the deforestation in future world moreover it doesn't matter who is the owner of this land may be women or men this happen in similar ways therefore this concept directly effects to the SDG especially gender equality target which was represented in upper. then what is the real concept of future women's land access according to the SDG while protecting the sustainability. Therefore the world needs to concentrations not increasing the land access in quantitatively because it directly over bound with the deforestation as a reason solutions are generating in the agricultural technology vices

\section{Conclusions}

The world population increasing the mush huger number in end of this century .especially the African population directly affected by the population growth makes number of social-cultural problems, may be some time it makes another disaster in future. therefore as the world we need to found sustainable solutions for this especially that solutions are generated by the technological innovations, therefore, world need to motivate technical education and experiment and research for the peaceful world, social science are not giving permanent solutions for this matters because social science are not generated tangible solutions for the problem surfaces therefore world need many technical innovations The push for economic growth in recent decades has led to substantial increases in wealth for large numbers of people across the globe. But despite huge gains in global economic output, there is evidence that our current social, political and economic systems are exacerbating inequalities, A growing body of research also suggests that rising income inequality is the cause of economic and social ills, ranging from low consumption to social and political unrest, and is damaging to our future economic well- being. Put simply, we need jobs for the hundreds of millions of unemployed people around the world, and we need the skilled employees that businesses are struggling to find. Every country will implement its own climate action plan that will be reviewed in 2018 and then every five years to ratchet up ambition levels. 


\section{REFERENCES}

Circuits and Systems: An International Journal (CSIJ), Vol.5, No.1/2/3, July 2018

[1] UN System Task Team (2012). Realizing the Future We Want for All, 23.

[2] World Bank. (2005). Gender Issues and Best Practices in Land Administration Projects: A Synthesis Report, 3.

[3] John Thornton, 2001. "Population Growth and Economic Growth: Long-Run Evidence from Latin America," Southern Economic Journal, Southern Economic Association, vol. 68(2), pages 464-468, October.

[4] David Lam, 2011. "How the World Survived the Population Bomb: Lessons From 50 Years of Extraordinary Demographic History," Demography, Springer; Population Association of America (PAA), vol. 48(4), pages 1231-1262, November.

[5] A.F. Darrat\& Y.K. Al-Yousif, 1999. "On the Long-Run Relationship between Population and Economic Growth: Some Time Series Evidence for Developing Countries," Eastern Economic Journal, Eastern Economic Association, vol. 25(3), pages 301-313, Summer.

[6] Fumitaka Furuoka, 2013. "Population and economic development in Indonesia: A revisit with new data and methods," ActaOeconomica, AkadémiaiKiadó, Hungary, vol. 63(4), pages 451-467,

December.," World Bank Publications, The World Bank, number 21634

[7] World Bank, 2015. "World Development Indicators 2015, June

[8] P. J. Dawson \& Richard Tiffin, 1998. "Is there a long-run relationship between population growth and living standards? The case of India," Journal of Development Studies, Taylor \& Francis Journals, vol. 34(5), pages 149-156.

[9] World Bank, United Nations Food and Agriculture Organization (FAO), and International Fund for Agricultural Development (IFAD) (2008). The Gender in Agriculture Sourcebook, Module 4, 125-171. See also: Fong, M. \& Bhushan, A. (1996). Toolkit on Gender in Agriculture. Gender Toolkit Series No. 1.

[10] Swedish International Development Cooperation Agency (SIDA). Quick Guide to What and How: Increasing Women's Access to Land. Women's Economic Empowerment Series.

[11] United Nations Food and Agriculture Organization (FAO) (2011).The State of Food and Agriculture: 2010-2011.

[12] United Nations Food and Agriculture Organization (FAO) (2011).The State of Food and Agriculture: 2010-2011.

[13] United Nations Food and Agriculture Organization (FAO) (2011).The State of Food and Agriculture: 2010-2011.

[14] UNDP (2008).Voices and Visions: The Asia Pacific Court of Women on HIV, Inheritance and Property Rights.

[15] Mehra, R. (1995). Women, Land and Sustainable Development. ICRW Working Paper No. 1.

[16]OECD Development Centre (2010). Gender Inequality and the MDGs: What are the Missing Dimensions

[17] United Nations Food and Agriculture Organization (FAO) (2012). Voluntary Guidelines on the Responsible Governance of Tenure of Land, Fisheries and Forests in the Context of National Food Security.

[18] Journal of Agricultural and Applied Economics, 40,2(August 2008) MaksymPolyakov and Daowei Zhang

[19] United Nations, Department of Economic and Social Affairs, Population Division (2015a)

[20] Trends in International Migrant Stock: The 2015 revision (United Nations database, POP/DB/MIG/Stock/Rev.2015).

[21] World Population Prospects: The 2015 Revision, DVD Edition.

[22] Global Trends Report 2014: World at War.

[23] World Bank (2015). Migration and Remittances: Recent Developments and Outlook. Special 


\section{BIBLIOGRAPHIES}

1. The "2 percent" (or "1 percent") figure has been widely reproduced, and most commonly traces citations back to the Food and Agriculture Organization of the United Nations (FAO). (www.landcoalition.org/publications/her-mile-women\%E2\%80\%99s-rights-and-access-land), Oxfam (/www.oxfam.org/en/node/2037), and Bread for the World (www.bread.org/what-we-do/resources/factsheets/empowering-women-in-agriculture.pdf).

2. Taken from the Bill and Melinda Gates Foundation (www.gatesfoundation.org/infographics/pages/women-in-agriculture-info.aspx).

3. UN System Task Team (2012). Realizing the Future We Want for All, 23.

4. World Bank. (2005). Gender Issues and Best Practices in Land Administration Projects: A Synthesis Report,

5. World Bank, United Nations Food and Agriculture Organization (FAO), and International Fund for Agricultur

6. United Nations Food and Agriculture Organization (FAO) (2012). Voluntary Guidelines on the Responsible Governance of Tenure of Land, Fisheries and Forests in the Context of National Food Security.

7. World Bank. (2005). Gender Issues and Best Practices in Land Administration Projects: A Synthesis Report,3.

8. Gender Equality And The Environment UNEP ( 2017)

9. https://www.weforum.org/agenda/2015/08/3-challenges-facing-the-uns-sustainable-development-goals/

10. https://www.devex.com/news/4-biggest-challenges-to-achieving-the-sdgs-87979

11 .The 2008 World Development Report presented compelling empirical evidence from a wide range of countries that supports this finding (World Bank, 2007)

12.A census of agriculture is a statistical operation for collecting, processing and disseminating data on the structure of agriculture, covering the whole or a significant part of thecountry.http://www.fao.org/docrep/013/i1595e/i1595e00.htm,http://www.fao.org/economic/ess/ess-

wca/wca-2000/ess-wca2000-tables/en/

13. http://www.fao.org/docrep/013/i2050e/i2050e.pdf

14. The FAO World Programmes of Agricultural Censuses follow a 10-year cycle.

15. Di Gregorio et al., 2008 cited in Lastarria-Cornhiel et al., 2014

16. https://esa.un.org/unpd/wpp/publications/files/key_findings_wpp_2015.pdf

17. http://www.who.int

18. Journal of Agricultural and Applied Economics, 40, 2(August 2008):649-666; Population Growth and Land Use Dynamics along Urban Rural Gradient; MaksymPolyakov and Daowei Zhang

19. Reducing risk exposure will become IM. Y. Wang, J. E. Overland, Geophys. Res. Lett.36,L07502 (2009)

20. W. Gregg, M. Conkright, P. Ginoux, J. O 'Reilly, N. Casey, Geophys. Res. Lett. 30, 1809 (2003)

21. Ocean and Coasts Program, Global Change Institute, Univer-city of Queensland, St. Lucia, QLD 4072, Australia. 2 Department of Marine Sciences, University of North Carolina, Chapel Hill, NC 27599, USA 22. https://www.ipcc.ch/pdf/assessment-report/ar5/syr/AR5_SYR_FINAL_SPM.pdf

23. R.J., and R.G. Healy. "Urban and Built-up Land Area Changes in the United States: An Empirical Investigation of Determinants." Land Economics

24. N.E. "Modeling Economics and Ecology: The Importance of a Spatial Perspective." American Journal of Agricultural Economics 78, 5(1996) 